\title{
A conferência nacional das cidades como instrumento de políticas públicas para o desenvolvimento territorial: a percepção dos conselheiros nos processos participativos e deliberativos
}

\author{
LAMOUNIER ERTHAL VILLELA \\ Universidade Federal Rural do Rio de Janeiro / Departamento de Ciências Econômicas, Programa de Pós-Graduação em \\ DesenVolvimento TerRitorial e Politicas Públicas, SeropédicA-RJ, BRASIL \\ MARCELO de OLIVEIRA VIDAL

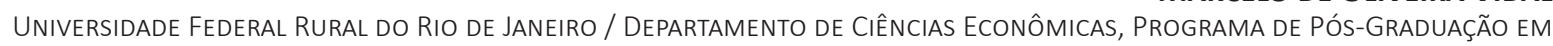 \\ DesenVolvimento Territorial e Politicas Públicas, SeropédicA-RJ, BRASIL \\ antonione Camelo de Araujo

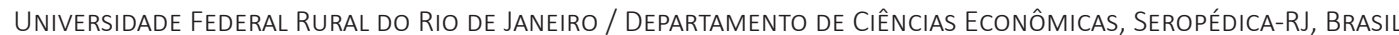 \\ NAYARA LUIZA SILVA FREIRE dA COSTA \\ Universidade Federal Rural do Rio de JaneIRo / Departamento de CIÊNCIAS ECONÔMICAS, SeropédicA-RJ, BRASIL
} EDUARDO GUSMÃO DA COSTA

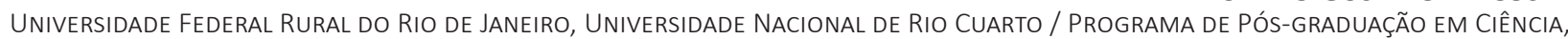
TECNOLOGIA E INOVAÇÃo EM AGROPECUÁRIA, SEROPÉdICA-RJ, BRASIL

\section{Resumo}

Os estudos em gestão social e desenvolvimento territorial defendem a ampliação das relações dialógicas entre sociedade civil, Estado e mercado nos processos deliberativos concernentes à esfera pública. Nesse sentido, os conselhos municipais e as conferências das cidades, que são o objeto deste artigo, surgem, entre outros instrumentos, com a finalidade de legitimar os processos participativos nas políticas públicas. Assim, este artigo tem por objetivo verificar a percepção dos conselheiros e delegados presentes nas conferências das cidades sobre a capacidade deliberativa dos conselhos municipais na condução das políticas públicas locais. Esse objetivo se justifica diante das crescentes manifestações populares ocorridas no Brasil em 2013, que clamavam pela democracia participativa e mudanças na condução das políticas públicas. Para elaborar esta pesquisa, diversas ações foram desenvolvidas, com destaque para as pesquisas de campo, a participação em conferências, a mediação de debates e a obtenção de depoimentos. Foram aplicados 102 questionários entre os conselheiros municipais durante as Conferências Estadual e Nacional das Cidades, realizadas, respectivamente, no Rio de Janeiro e em Brasília, em 2013. Os resultados apontam contradições entre a percepção dos conselheiros sobre os problemas locais e sua real capacidade de intervir nas deliberações dos poderes públicos locais Ou seja, eles têm grande conhecimento sobre os problemas das localidades que representam, porém, pequena capacidade deliberativa.

Palavras-chave: Gestão social. Conselhos municipais. Desenvolvimento local.

The national conference of cities as an instrument of public policies for territorial development: the perception of councilors in participatory and deliberative procedures

\section{Abstract}

Studies in social management and territorial development advocate for the expansion of dialogical relations between civil society, State, and market in deliberative procedures concerning the public sphere. In this sense, municipal councils and conferences of cities, which are the object of analysis in this article, arise among other instruments, in order to legitimize participatory procedures in public policies. Thus, this article aims to verify the perception of councilors and delegates attending the conferences of cities on the deliberative ability of municipal councils in conducting public policies. This objective is justified in face of the growing popular manifestations that occurred in Brazil in 2013, crying out for participatory democracy and changes on the conduction of public policies. To prepare this research, many actions were taken, with an emphasis on field survey, participation in conferences, mediation of debates, and collection of testimonials. We applied 102 questionnaires among the municipal councilors during the State and National Conferences of Cities, held, respectively, in Rio de Janeiro and Brasilia, in 2013. The results point out contradictions between the perception of councilors on local problems and their actual ability to intervene with deliberations by local public authorities. That is, they have great knowledge about the problems in the locations they represent, but a low deliberative ability.

Keywords: Social management. Municipal councils. Local development.

La conferencia nacional de las ciudades como un instrumento de política pública para el desarrollo territorial: la percepción de los asesores en los procesos de deliberación y de participación

Resumen

Los estudios en gestión social y desarrollo territorial indican la ampliación de las relaciones dialógicas entre sociedad civil, Estado y mercado en los procesos de deliberación relativos a la esfera pública. En este sentido, los consejos municipales y las conferencias de las ciudades, que constituyen el objeto de este artículo, emergen, entre otros instrumentos, con el fin de legitimar los procesos de participación en las políticas públicas. Así, este artículo tiene como objetivo verificar la percepción de los consejeros y delegados presentes en las conferencias de las ciudades acerca de la capacidad de deliberación de los consejos municipales en la conducción de las políticas públicas locales. Este objetivo se justifica ante las crecientes manifestaciones populares ocurridas en Brasil en 2013, que clamaban por la democracia participativa y cambios en la conducción de las políticas públicas. Para preparar esta investigación, varias acciones se desarrollaron, especialmente en las investigaciones de campo, la participación en conferencias, la mediación de debates y la obtención de testimonios. Se aplicaron 102 cuestionarios entre los consejeros municipales durante las Conferencias de Estado y Nacional de las Ciudades, realizadas, respectivamente, en Río de Janeiro y Brasilia, en 2013. Los resultados indican contradicciones entre la percepción de los consejeros acerca de los problemas locales y su real capacidad para intervenir en las deliberaciones de los poderes públicos locales. Es decir, tienen un gran conocimiento de los problemas de las localidades que representan, pero pequeña capacidad de deliberación.

Palabras clave: Gestión social. Consejos municipales. Desarrollo local. 
A conferência nacional das cidades como instrumento de políticas públicas para o desenvolvimento territorial: a percepção dos conselheiros nos processos participativos e deliberativos
Lamounier Erthal Villela |Marcelo de Oliveira Vidal | Antonione Camelo de Araujo | Nayara Luiza Silva Freire da Costa Eduardo Gusmão da Costa

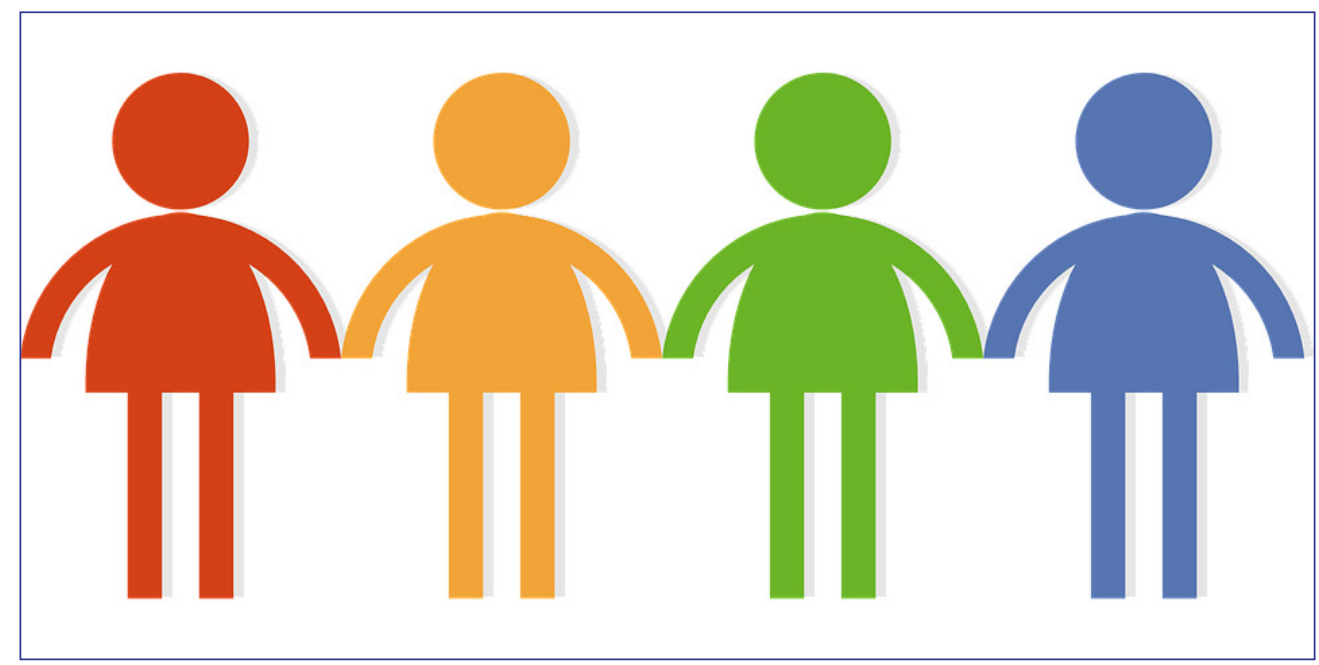

\section{INTRODUÇÃO}

A fim de compreender como vem se desenvolvendo o papel dos conselhos municipais nos processos participativos e deliberativos da gestão pública municipal, um grupo de pesquisa inicia as atividades de campo no âmbito do município de Itaguaí-RJ. Atualmente, esse município passa por fortes mudanças estruturais induzidas por grandes empreendimentos locais que alteram toda a lógica produtiva tradicionalmente estabelecida e ameaça o bem-estar comum a despeito da vultuosidade das inversões.

O grupo de estudos foi convidado a participar como expositor, observador e participante da Comissão preparatória da 5a Conferência Municipal da Cidade de Itaguaí, em 18 de maio de 2013, onde palestrou sobre os Eixos 1 e 3 do evento, respectivamente, "Participação e Controle Social no Sistema Nacional de Desenvolvimento Urbano" (SNDU) e "Instrumentos e Políticas de Integração Intersetorial e Territorial". Posteriormente, o grupo participou como observador das conferências no âmbito estadual, ocorridas em 12 e 13 de outubro de 2013, na cidade do Rio de Janeiro, onde 43 questionários foram aplicados, e da Conferência Nacional, ocorrida em Brasília, entre 20 e 24 de novembro de 2013, quando foram aplicados outros 59 questionários. Durante a pesquisa de campo, o grupo também participou das sessões, debates e votações que deram origem às propostas, conforme a metodologia das conferências nacionais (IPEA, 2012).

Logo, o objetivo deste artigo é verificar a percepção dos conselheiros e delegados presentes nas conferências das cidades sobre a capacidade deliberativa dos conselhos municipais na condução das políticas públicas locais. Esse objetivo se justifica diante das crescentes manifestações populares ocorridas no país em 2013, que clamaram por uma ampliação do poder deliberativo na sociedade, mudanças na condução das políticas públicas, passando do modelo "top-down" para o modelo "bottom-up", ou seja, pela ampliação da democracia participativa. A desordem urbana em todos os níveis (planos diretores falhos, mobilidade urbana, problemas sociais e ambientais), resultado de processos históricos que não levavam em conta o planejamento ou a reforma urbana, tornam a criação dos mecanismos de participação popular ainda mais importantes e urgentes.

Teoricamente, os avanços obtidos no âmbito das políticas públicas (LASCOUMES e LE GALÈS, 2004; GAUDIN, 2007) e na gestão social (TENÓRIO, 2006) preconizam uma cidadania deliberativa (HARBERMAS, 1984) como modo de ampliar o diálogo entre os entes "Estado, mercado e sociedade". No entanto, as realidades locais, assim como o forte jogo de poder, representam uma forte inércia relativa às mudanças teoricamente possíveis e viáveis.

* Fonte da imagem: Pixabay. Disponível em https://pixabay.com/pt/comunidade-multidão-grupo-homem-150124/. Acesso em 25 maio 2016. 
A conferência nacional das cidades como instrumento de políticas públicas para o desenvolvimento territorial: a percepção dos conselheiros nos processos participativos e deliberativos
Lamounier Erthal Villela |Marcelo de Oliveira Vidal | Antonione Camelo de Araujo | Nayara Luiza Silva Freire da Costa Eduardo Gusmão da Costa

Dessa forma, uma postura crítica é possível ao comparar a percepção dos conselheiros com as realidades locais e a capacidade de agir das instâncias analisadas. A suposição que origina este artigo é que o modelo de gestão municipal não só se mostra incapaz de responder às demandas da sociedade como amplia os problemas de bem-estar social ao gerar uma crise de governabilidade e ampliação dos custos de transação do mercado. Supõe-se, também, que o modelo de gestão participativo e dialógico represente uma mudança paradigmática nos tradicionais modelos de gestão municipais, caracterizados na literatura brasileira como clientelistas e patrimonialistas (DINIZ, 1978; BAHIA, 2003).

Apesar da amplitude de questões relacionadas ao objeto deste estudo, a delimitação foi a percepção dos conselheiros nos processos deliberativos e a dinâmica das conferências. Além desta introdução e das observações finais, o artigo está estruturado em quatro seções A primeira apresenta os aspectos relativos às estruturas propostas pelo Ministério das Cidades, em seguida aborda-se o referencial teórico que origina o instrumento de coleta de dados, que foi aplicado nas conferências no âmbito do estado do Rio de Janeiro e da nacional em Brasília. Na terceira seção abordam-se os aspectos metodológicos e na quarta os resultados são tabulados e comentados.

\section{OS INSTRUMENTOS DE GOVERNO PARA A PARTICIPAÇÃO SOCIAL NO BRASIL}

Alguns instrumentos de governo para a participação social no Brasil são recentes e ainda pouco estudados. Sem esses instrumentos, a gestão social torna-se improvável e a tendência do poder público servir exclusivamente aos interesses do capital se amplia. Não é por acaso que muitas questões sociais e urbanas foram deixadas de lado no planejamento de nossas cidades, o que ocasionou deficiências graves no desenvolvimento do território. A questão urbana como um problema social no Brasil surge a partir do contexto desenvolvimentista da década de 1960, onde se defendia a necessidade de implementar reformas de base para o alargamento do mercado interno e melhores condições de vida para a população (IPEA, 2012). Após a interrupção durante o período militar, o movimento ressurge de forma mais descentralizada, intervindo decisivamente no campo das políticas urbanas locais e atuando em todos os níveis de governo. Apenas a partir daí começa a surgir um debate sobre a questão urbana na agenda da política nacional, bem como interlocutores com a sociedade, que almejavam facilitar a negociação entre os atores. Dessa forma, a atuação dos governos locais e a participação dos atores locais na formulação e implementação de políticas públicas voltadas à cidade inicia um processo embrionário graças, em boa parte, à criação de instrumentos de promoção da participação social.

\section{Ministério das Cidades}

O Ministério das Cidades surgiu como um instrumento para atender as demandas sociais a partir dos anos 2000, em um contexto pós-neoliberal, que previa a remontagem do aparelho estatal. Com foco inicial na questão da habitação, vê-se a necessidade de ampliação do Ministério das Cidades, em virtude da evolução do debate, que tinha como crítica a ausência de política urbana no Brasil e a falta de um espaço institucional que se responsabilizasse pela questão. Ao mesmo tempo, a questão da habitação não engloba apenas casas, mas a melhoria da qualidade da água, saúde, esgoto, drenagem, coleta de lixo, transporte, trânsito seguro e lazer. Para alcançar tais fins, foi criado um Sistema Nacional de Habitação do qual faziam parte o Ministério das Cidades, os Conselhos Nacional, Estadual e Municipal de Desenvolvimento Urbano, os Fundos de Moradia nas três esferas, a Agência Nacional de Regulamentação do Financiamento Habitacional e os agentes promotores e financeiros, públicos e privados.

A proposta do Ministério das Cidades se concentrava em formular e conduzir uma política de desenvolvimento urbano para o Brasil, integrando os setores de habitação, saneamento ambiental, trânsito e mobilidade urbana, planejamento e gestão territorial e fundiária. O Ministério nasce com o objetivo de ampliar fóruns de participação social, dessa forma, almeja a realização de conferências em todas as esferas de governo, com o objetivo de garantir uma ampla representação e participação de todos os segmentos. As Conferências trariam para a prática o conceito de cidadania deliberativa, conforme as premissa habermasianas, defendidas no Brasil por Tenório (2012, p. 22): 
A conferência nacional das cidades como instrumento de políticas públicas para o desenvolvimento territorial: a percepção dos conselheiros nos processos participativos e deliberativos
Lamounier Erthal Villela | Marcelo de Oliveira Vidal | Antonione Camelo de Araujo | Nayara Luiza Silva Freire da Costa | Eduardo Gusmão da Costa

[...] a característica central de esfera pública é tomada pela busca de soluções por meio da concordância dos diferentes atores participantes do processo decisório. A esfera pública seria o espaço no qual se constituem experiências de interação social, o foro reflexivo no qual os atores de uma sociedade buscam soluções comuns.

Nesse sentido, o Ministério das Cidades almeja exatamente cumprir o papel de servir como instrumento para a busca de soluções entre poder público, iniciativa privada e sociedade civil.

\section{Conselho das cidades}

O conselho das Cidades nasce no mesmo contexto, atrelado à necessidade de proporcionar um instrumento que assegurasse o desenvolvimento e acompanhamento da política urbana no Brasil. Entre as muitas atribuições contidas em regimento interno, o conselho almeja: formular programas, instrumentos, normas e prioridades da Política Nacional de Desenvolvimento Urbano; estimular ações que visam a proporcionar a geração, apropriação e utilização de conhecimentos científicos, tecnológicos, gerenciais e organizativos pelas populações das áreas urbanas, assim como realização de estudos, debates e pesquisas sobre a aplicação e os resultados estratégicos alcançados pelos programas e projetos desenvolvidos pelo Ministério das Cidades; estimular a ampliação e o aperfeiçoamento dos mecanismos de participação social; acompanhar e avaliar o cumprimento das resoluções das conferências nacionais das cidades.

O ConCidades almeja ser um instrumento fundamental para fazer valer as finalidades das conferências nacionais, que partem do consenso dos mais diversos segmentos da sociedade civil organizada. O órgão conta com as seguintes entidades membro: presidente (que é o Ministro de Estado das Cidades); plenário (composto por 86 representantes de diferentes segmentos - 16 representantes do poder público federal, 9 representantes do poder público estadual e do Distrito Federal, 12 representantes do poder público municipal, 23 representantes de entidades de movimentos populares, 8 representantes de entidades empresariais, 8 representantes de entidades de trabalhadores, 6 representantes de entidades profissionais acadêmicas e de pesquisa, 4 representantes de organizações não governamentais; secretaria-executiva do ConCidades; comitês técnicos (habitação, saneamento básico, trânsito, transporte e mobilidade urbana e planejamento e gestão do solo urbano).

\section{Conferências das cidades}

Do ponto de vista deste artigo, as conferências representam um fortalecimento do marco participativo presente na Constituição de 1988. De acordo com o texto constitucional, a soberania popular pode se fazer tanto pela via representativa como pela via da participação. Segundo o Instituto de Pesquisa Econômica Aplicada (IPEA, 2012), as conferências podem ser entendidas como processos participativos convocados por órgãos do Poder Executivo que reúnem, com certa periodicidade, representantes do Estado e da sociedade para dialogar a respeito de políticas públicas. O instituto as caracteriza considerando os seguintes elementos: inserem-se em uma etapa do ciclo de gestão de políticas públicas; reúnem sujeitos políticos diversos; conectam-se a outras instituições participativas; e desenvolvem-se como processos participativos. O processo de formação e realização das conferências nacionais das cidades por meio dessa estrutura almeja, em três etapas (municipal; estadual e do distrito Federal; e nacional), alcançar alguns objetivos, tais como os enumerados pelo Ministério das Cidades:

I - Identificar os principais problemas que afligem as populações das cidades brasileiras, mediante manifestações de vários segmentos e agentes produtores, consumidores e gestores;

II - Propor princípios e diretrizes das políticas setoriais e da política nacional das cidades;

III - Avaliar os programas e legislações nas áreas de habitação, saneamento ambiental, programas urbanos, trânsito, transporte e mobilidade urbana, desenvolvidas pelos governos federal, estaduais, municipais e do Distrito Federal;

IV - Indicar ao ministério das cidades as prioridades de atuação;

V - Avaliar o sistema de gestão e implementação das políticas urbanas, intermediando a relação com a sociedade na busca da construção de uma esfera público-participativa; 
A conferência nacional das cidades como instrumento de políticas públicas para o desenvolvimento territorial: a percepção dos conselheiros nos processos participativos e deliberativos
Lamounier Erthal Villela |Marcelo de Oliveira Vidal | Antonione Camelo de Araujo | Nayara Luiza Silva Freire da Costa Eduardo Gusmão da Costa

VI-Avaliar os instrumentos de participação popular presentes na elaboração e implementação das políticas públicas e propor as formas de participação no processo de formação do Conselho das Cidades. (BRASIL, MINISTÉRIO DAS CIDADES, p. 2)

As primeiras conferências realizadas no Brasil serviram ao objetivo político de ampliação da articulação federativa para melhoria da gestão de ações nos diferentes níveis da Federação. Apesar da participação ser insipiente, a conferência passou a servir como veículo de expressão das preocupações existentes em setores da sociedade. Como já destacado, o envolvimento da sociedade aumenta com a redemocratização do país. No processo histórico, o que se observa é uma mudança progressiva de um modelo que servia aos propósitos de uma administração centralizada para um modelo que se insere em uma lógica de descentralização e participação social. No que concerne à quantidade de pessoas que participam das conferências, contabilizando o registro de participantes de todas as etapas, observa-se que $73 \%$ das conferências possuem um total de até 100 mil participantes, sendo o menos número observado 4.763 e o maior 524.461 (IPEA, 2012).

Ainda que muitos aspectos do desenho institucional original das conferências tenha se mantido, a mudança para o caráter mobilizatório-político impulsionou outras áreas de políticas públicas a instituírem esse tipo de arranjo institucional para a participação social na gestão pública. A literatura e análise dos documentos das conferências possibilitam dizer que são instrumentos que permitem o diálogo entre Estado e sociedade convocados pelo Poder Executivo e desenvolvidos em etapas interconectadas pela escolha de representantes e pela formulação de propostas para políticas públicas.

O debate gerado nos três níveis nos quais ocorre a Conferência Nacional das Cidades (municipal, estadual - incluindo o Distrito Federal -, e nacional) tem por base um documento de discussão que está dividido em três partes: 1) texto base nacional; 2) texto com as prioridades do Ministério das Cidades para a Política de Desenvolvimento Urbano 2014-2016; 3) texto para discussão das prioridades municipais e estaduais (incluindo o Distrito Federal) para a Política de Desenvolvimento Urbano 2014-2016.

O primeiro, o texto base nacional, que aborda quatro grandes temas relacionados diretamente ao SNDU, e o segundo, que contém as prioridades do Ministério das Cidades para a política de desenvolvimento urbano, passam pelo mesmo processo até chegar à etapa nacional. Na etapa municipal são feitas propostas aditivas, supressivas ou modificativas aos textos e determinadas em plenária para, então, ser enviadas para a etapa estadual. Na conferência estadual, o processo será de discussão e votação em plenária das propostas que irão para a etapa nacional, onde, enfim, será deliberado para chegar à versão final dos documentos, o texto base com as emendas finda na resolução da conferência e as prioridades do Ministério das Cidades resulta no relatório final da conferência.

Para o debate sobre as propostas de emendas no texto base, na etapa nacional são organizados painéis de discussão. Para determinação das prioridades do Ministério das Cidades, os delegados se organizam em grupos e levam as propostas que serão votadas em plenária. Além desses 2 documentos outros 2 relatórios são organizados e enviados para a conferência nacional, para fins de conhecimento apenas, não há discussões ou deliberações sobre esses relatórios nesta última etapa. São eles: a) o relatório que contém as prioridades municipais e estaduais para a Política de Desenvolvimento Urbano 2014-2016, que é elaborado na etapa municipal; b) o relatório que contém as prioridades estaduais para a Política de Desenvolvimento Urbano 2014-2016, que é elaborado na etapa estadual. É importante destacar que as duas primeiras etapas (municipal e estadual) são responsáveis pela eleição de seus conselhos de acordo com seus respectivos níveis, nas conferências municipais é determinado o Conselho Municipal das Cidades e nas estaduais o Conselho Estadual das Cidades.

O texto base nacional, que inclui as propostas de emendas aditivas, supressivas ou modificativas elaboradas nas conferências municipais e estaduais foi discutido e aprovado em plenário, tendo sido as propostas organizadas por eixo temático. 0 resultado final da votação formaria o relatório nacional da 5a Conferência Nacional das Cidades. Após a deliberação sobre propostas, estas seriam levadas à plenária para a votação. Do resultado, elabora-se o relatório final da 5a Conferência Nacional das Cidades.

Representantes de diferentes movimentos se deslocam pelo Brasil inteiro, para participar do evento que almeja incentivar e promover a participação de diferentes atores na formulação de políticas para reforma urbana. Os participantes da conferência são divididos em duas categorias: os delegados, com direito a voz e voto, e os observadores. A Tabela 1 apresenta a distribuição de delegados entre os diferentes segmentos e mostra que o movimento popular é o que contém maior número de representantes. 
A conferência nacional das cidades como instrumento de políticas públicas para o desenvolvimento territorial: a percepção dos conselheiros nos processos participativos e deliberativos
Lamounier Erthal Villela | Marcelo de Oliveira Vidal | Antonione Camelo de Araujo | Nayara Luiza Silva Freire da Costa | Eduardo Gusmão da Costa

Tabela 1

Distribuição de Delegados por Segmento

\begin{tabular}{|c|c|c|c|c|c|c|c|c|}
\hline $\begin{array}{c}\text { Segmento } \\
\text { Indicador }\end{array}$ & $\begin{array}{c}\text { Poder Público } \\
\text { Estadual } \\
\text { Delegados }\end{array}$ & $\begin{array}{c}\text { Poder público } \\
\text { Municipal } \\
23.37 \%\end{array}$ & $\begin{array}{c}\text { Movimento } \\
\text { Popular } \\
11,05 \%\end{array}$ & $\begin{array}{c}\text { Empresários } \\
11,05 \%\end{array}$ & $\begin{array}{c}\text { Trabalhador } \\
11,05 \%\end{array}$ & $\begin{array}{c}\text { Professores } \\
\text { Ocademicos }\end{array}$ \\
\hline Delegados & 561 & 75 & 126 & 167 & 62 & 62 & 26 & $4,66 \%$ \\
\hline
\end{tabular}

Fonte: Elaborado pelos autores.

Em 2013, os delegados discutiram nas conferências das cidades os seguintes temas:

- Saneamento ambiental: integrar transversalmente as políticas, o planejamento e as ações públicas de habitação, saneamento, trânsito, transporte e mobilidade, superar a cultura de fragmentação, criar mecanismos e instrumentos para garantir o acesso e a otimização da aplicação integrada dos fundos específicos que estejam em conformidade com o que preconiza a Constituição Federal e legislações complementares, para ofertar habitação nos padrões de infraestrutura urbana e sustentabilidade, priorizando a qualidade de vida dos cidadãos.

- Mobilidade urbana e trânsito: implementar as propostas do Pacto Nacional da Mobilidade Urbana (conforme resolução do Conselho Nacional das Cidades, de 2 de outubro de 2013) e incentivar e financiar a elaboração participativa dos planos de mobilidade e acessibilidade urbana, integrado ao plano diretor municipal, concomitante com a capacitação e apoio técnico aos agentes locais.

- Capacitação e assistência técnica: apoiar e capacitar os pequenos municípios na implantação de políticas urbanas, criação do Sistema de Desenvolvimento Urbano Municipal, disponibilizando recursos técnicos e financeiros para a elaboração e implantação de plano diretor participativo.

- Financiamento da política urbana: implementar o Fundo Nacional de Desenvolvimento Urbano (FNDU) para aplicação nas políticas de desenvolvimento urbano, vinculado à criação de instrumentos para fiscalização da aplicação dos recursos do fundo, possibilitando o controle social.

- Participação, controle social e conselhos: implementar políticas de capacitação e formação continuada de conselheiros, das equipes técnicas (municipais, estaduais e federal), dos movimentos populares, dos segmentos e da sociedade civil, em geral, sobre programas da política do SNDU.

- Política territorial e regularização fundiária: ampliar a disponibilização de recursos técnicos e financeiros para a elaboração, revisão e implementação dos planos diretores municipais, inclusive para os pequenos municípios, e dos planos diretores metropolitanos, assim como das legislações complementares e projetos estratégicos, garantindo e condicionando os recursos do Ministério das Cidades à regulamentação e implementação dos instrumentos do Estatuto da Cidade em sua integralidade, no prazo de até 2 anos a partir da 5a Conferência Nacional das Cidades.

- Habitação: aplicar os instrumentos do Estatuto da Cidade, de modo a garantir a destinação dos terrenos e imóveis desocupados para a produção habitacional para populações de baixa renda, bem como utilizar terrenos e imóveis ociosos do poder público, em todas as três esferas para o mesmo fim, priorizando-se as de maior vulnerabilidade social.

\section{REFERENCIAL TEÓRICO}

A importância dos conceitos de gestão social e do desenvolvimento territorial sustentável para as conferências da cidade

A fragmentação, complexidade e interdependência de nossas sociedades atuais provocam a necessidade de compatibilizar a democracia representativa com novas formas de democracia participativa, mais direta e deliberativa, ou seja, com alternativas que deem voz e rosto à cidadania plural. Trata-se de fortalecer a democracia mediante uma nova maneira de tomar decisões que transfira aos cidadãos poder e responsabilidade nos assuntos públicos (PASTOR SELLER, 2004). Na mesma linha, Font (2004, p. 28, tradução nossa) destaca a necessidade de instrumentalizar as formas de participação popular: 
A conferência nacional das cidades como instrumento de políticas públicas para o desenvolvimento territorial: a percepção dos conselheiros nos processos participativos e deliberativos
Lamounier Erthal Villela |Marcelo de Oliveira Vidal | Antonione Camelo de Araujo | Nayara Luiza Silva Freire da Costa Eduardo Gusmão da Costa

1. Reforçar a participação popular. É necessário que a representatividade seja cada vez maior, para que os mecanismos da democracia exerçam a pressão necessária. Definido o protagonismo da população no processo decisório, ele não pode se constituir apenas na forma de reuniões consultivas, as pessoas devem participar do processo de definição de prioridades, de adoção de políticas e de aplicação e avaliação delas.

2. Buscar a participação do cidadão não organizado por meio da ampliação dos mecanismos de participação, que atualmente são escassos [...].

3. Impulsionar uma mudança em busca de cultura mais participativa no médio prazo. Isso exigiria um diagnóstico mais preciso sobre as causas da omissão da participação cidadã. Seria necessária uma mudança de conduta institucional, bem como a existência de mais mecanismos de consulta na tomada de decisões, além de um esforço de educação democrática e participativa que partisse dessas instituições, do sistema educativo e dos meios de comunicação.

No Brasil, a temática de participação social tem sido discutida sob o conceito de gestão social. A despeito da amplitude conceitual referente aos estudos da gestão social, destacamos a ideia de Botrel, Araújo e Pereira (2010), para quem a gestão social se desenvolve no âmbito da esfera pública, onde se sobressaem as organizações públicas não estatais e o interesse público da sociedade, além de proporcionar condições à emancipação dos indivíduos, baseando-se na democracia deliberativa, na formação da consciência crítica de seres humanos dotados de razão (TENÓRIO, 2006). Nesse contexto, o papel do Estado passa a ser a coordenação de interesses divergentes em busca de critérios de redistribuição, a exemplo do que se almeja com as conferências das cidades.

$\mathrm{Na}$ atual conjuntura, observa-se uma dupla crise onde o socialismo declina por um lado e a social-democracia junto com o Estado de bem-estar por outro, a construção do conceito de gestão social ocorre, inicialmente, pela análise dos pares de palavras Estado-sociedade e capital-trabalho, que são invertidas para sociedade-Estado e trabalho-capital, ressaltando a importância da sociedade e do trabalho como protagonistas dessas relações. Ampliando a discussão, insere-se o par de palavras sociedade-mercado, que representa o processo de interação da sociedade civil organizada com o mercado, no qual a sociedade também deve ser protagonista (TENÓRIO, 2008a; 2008b). As conferências das cidades buscam exatamente mobilizar a sociedade civil nessa dialética sociedade-mercado promovida pelo poder público. Assim, a partir de uma perspectiva republicana, o poder soberano que, antes, no Estado absolutista, estava centrado no monarca ou no imperador e que no Estado moderno passou para a burguesia, poderia agora estar se direcionando para a sociedade civil. É importante destacar que o significado da expressão "sociedade civil", que é aquela que participa ativamente das conferências, não coincide com a expressão "sociedade burguesa", de tradição liberal. Habermas (1984) destaca que o núcleo institucional da sociedade civil é formado por associações e organizações livres, não estatais e não econômicas, as quais ancoram as estruturas de comunicação da esfera pública nos componentes sociais do mundo da vida.

Na mesma linha, Tenório (2012) propõe que a cidadania deliberativa deve intermediar a relação entre esses pares de palavras; para o autor: "Cidadania deliberativa significa, em linhas gerais, que a legitimidade das decisões deve ter origem em processos de discussão orientados pelos princípios da inclusão, do pluralismo, da igualdade participativa, da autonomia e do bem comum" (TENÓRIO, 2008a, p. 160). A cidadania deliberativa "faz jus à multiplicidade de formas de comunicação" e "une os cidadãos em torno de um auto entendimento ético" (TENÓRIO, 2008b, p. 167). Sob essa perspectiva, a esfera pública seria o espaço de intermediação entre Estado, sociedade e mercado, bem como a cidadania deliberativa seria o processo participativo de deliberação baseado essencialmente no entendimento entre as partes, sendo o procedimento da prática da cidadania deliberativa na Esfera Pública a participação.

Diferente de um processo centralizador, tecnoburocrático, elaborado em gabinetes, em que o conhecimento técnico é o principal argumento da decisão, sob uma perspectiva descentralizadora, de concepção dialógica, a Esfera Pública deve identificar, compreender, problematizar e propor as soluções dos problemas da sociedade, a ponto de serem assumidas como políticas públicas pelo contexto parlamentar e executadas pelo aparato administrativo de governo (TENÓRIO, 2008b, p. 162).

A gestão social seria o caminho para a emancipação, pois incita a um "gerenciamento mais participativo, dialógico, no qual o processo decisório é exercido por meio de diferentes sujeitos sociais" (TENÓRIO, 2008b, p. 25-26). Na gestão social, "a hegemonia das ações possui caráter intersubjetivo, isto é, onde os interessados na decisão, na ação de interesse público, são participantes do processo decisório" (TENÓRIO e SARAIVA, 2006, p. 128). Ao mesmo tempo, a gestão social surge como 
A conferência nacional das cidades como instrumento de políticas públicas para o desenvolvimento territorial: a percepção dos conselheiros nos processos participativos e deliberativos
Lamounier Erthal Villela |Marcelo de Oliveira Vidal | Antonione Camelo de Araujo | Nayara Luiza Silva Freire da Costa Eduardo Gusmão da Costa

um contraponto à gestão burocrática do Estado e do mercado, para cuidar do interesse público não estatal e alcançar o bem comum na perspectiva republicana.

As conferências da cidade apostam na ideia de que a gestão das demandas da sociedade pode ocorrer para além do Estado, via sociedade. Por outro lado, a gestão social enquanto processo, vista como uma modalidade específica de gestão (nível organizacional) busca "subordinar as lógicas instrumentais [típicas da gestão privada/estratégica] a outras lógicas, mais sociais, políticas, culturais ou ecológicas" (FRANÇA FILHO, 2008, p. 30).

[A gestão social] corresponde então ao modo de gestão próprio às organizações atuando num circuito que não é originariamente aquele do mercado e do Estado, muito embora estas organizações entretenham, em grande parte dos casos, relações com instituições privadas e públicas, por meio de variadas formas de parcerias para consecução de projetos. Este é o espaço próprio da chamada sociedade civil, portanto, uma esfera pública de ação que não é estatal (FRANÇA FILHO, 2008, p. 32).

Fischer (2002, p. 29) apresenta a gestão social como "gestão do desenvolvimento social”, definido pela autora como um espaço "reflexivo das práticas e do conhecimento constituído por múltiplas disciplinas". A gestão social seria, ainda, uma "proposta pré-paradigmática" que vem recebendo a atenção de muitos centros de pesquisa no Brasil e no exterior (FISCHER, 2002; FISCHER e MELO, 2006). Assim, "a Gestão Social pode ser definida como aquela orientada para o social (enquanto finalidade) pelo social (enquanto processo), norteada pelos princípios da ética e da solidariedade" (FISCHER e MELO, 2006, p. 17). Um conceito importante para entender a perspectiva de Fischer (2002) e a de Fischer e Melo (2003; 2006) sobre gestão social e a própria atividade do gestor social é o de interorganizações. Os conceitos-chave para se entender as interorganizações são: território, redes sociais, redes de redes (FISCHER e MELO, 2006).

Nesse contexto percebe-se a clara conexão entre os conceitos de gestão social e desenvolvimento territorial sustentável, onde a condição para este passa pela participação e pela gestão social. Pinho (2010, p. 32) classifica a participação "como seminal para apresentar a Gestão Social". Nesse sentido, argumenta-se que o contexto nacional é diferente do europeu, onde o sucesso da participação está baseado nas "suas instituições sólidas e estáveis, além de nível de vida elevado, baixa disparidade socioeconômica e as reconfortantes virtudes cívicas de solidariedade e de moderação" (BENEVIDES, 1999 apud PINHO, 2010, p. 33), pois "a Alemanha de Habermas não é definitivamente aqui! Todas as condições requeridas pelo referencial habermasiano nos faltam, ainda que estejam em (lenta) construção" (PINHO, 2010, p. 33). Para Crozier (1989) o Estado ocidental, de forma geral, está atrasado em relação à sociedade, pois continua arrogante e autoritário, ou seja, a crise da gestão pública no mundo ocidental é universal, tanto nos países ricos como nos países pobres. O que se observa no Brasil é que as disparidades socioeconômicas, entre outras causas, de fato, dificultam muito o processo de participação social, ainda que aspectos positivos possam ser ressaltados. Por outro lado, a integração da sociedade civil no processo decisório parece ser uma das poucas alternativas viáveis no que se refere a mudanças estruturais.

As condições para uma participação efetiva da sociedade nos processos decisórios passam, entre outras coisas, por políticas públicas de melhor qualidade e, entre elas, aquelas que se voltem à educação, ou seja, a efetividade da cidadania deliberativa, da forma colocada por Jürgen Habermas, passa também por políticas de desenvolvimento anteriores à participação social, o que sugere mais que uma relação de causa e efeito entre os conceitos, mas uma relação de interdependência.

Da mesma forma, a sociologia econômica contemporânea oferece ferramentas especialmente importantes para o estudo da ligação entre os territórios e a gestão social. Os trabalhos do sociólogo norte-americano Neil Fligstein (2001) como também tratado por Bourdieu (2000) oferecem instrumentos teóricos consistentes para a compreensão de dinâmicas territoriais. Dois temas fundamentais podem ser evocados nesse sentido.

A ideia central de Fligstein (2001) é que, em cada campo, objetivo central da ação está na tentativa de alcançar cooperação com outros atores. As pessoas que agem como líderes nos grupos precisam estabilizar suas relações com os membros de seus grupos para conseguir que estes ajam coletivamente e precisam estruturar seus movimentos estratégicos em direção a outras organizações em seus campos. A habilidade dos atores para analisar e conseguir tal cooperação pode ser vista, genericamente, como habilidade social (social skill). 
A conferência nacional das cidades como instrumento de políticas públicas para o desenvolvimento territorial: a percepção dos conselheiros nos processos participativos e deliberativos
Lamounier Erthal Villela | Marcelo de Oliveira Vidal | Antonione Camelo de Araujo | Nayara Luiza Silva Freire da Costa Eduardo Gusmão da Costa

Encarar os territórios como campos em que se defrontam protagonistas com interesses diversos e trabalhar pela gestão social desses interesses com o objetivo de promover a democracia participativa, é o objetivo último deste estudo, que se inicia por meio da apreensão das percepções dos conselheiros municipais. Segundo Parés e Castellà (2008), nas últimas décadas, municípios ao redor do mundo têm desenvolvido experiências muito diversas de democracia participativa, como a dos Conselhos Municipais, em busca de novas formas para governar sociedades cada vez mais complexas. No entanto, os autores questionam até que ponto essas experiências resultam em um incremento efetivo de qualidade na democracia desses municípios ou unicamente representam um aumento no número de experiências participativas. Nesse sentido, defendem que a academia necessita de um processo de reflexão sobre a qualidade das múltiplas experiências surgidas no âmbito da participação cidadã e consideram imprescindível sua avaliação e caracterização para poder, assim, melhorá-las. A avaliação da participação cidadã se configura como uma ferramenta capaz de qualificar as experiências participativas, identificando suas debilidades e seus pontos fortes para estabelecer as bases para o desenvolvimento territorial sustentável.

Gaudin (2007) explica como, na França, o processo participativo foi se ampliando com o fim da centralização dos poderes públicos. A lógica da descentralização teve de buscar novos instrumentos de gestão e estes foram sendo construídos à medida que se ampliavam os problemas locais e as dificuldades para estabelecer novas lógicas na gestão publica. Ele ilustra o fato como o fim do "jardim francês", ou seja, cada problema local deveria passar por fóruns de debates e encontrar soluções diferentes das pensadas pelos Tecnotables; em francês, a junção de tecnocratas com notáveis. Estes "notáveis" não detinham mais capacidade de resolver os problemas distantes dos palácios públicos, e a burocracia deveria ser reinventada buscando apoio da base, ou seja, inverter a lógica de cima para baixo, passando, então, a ter as "mãos na massa", dentro da perspectiva política denominada bottom-up. Nesse caso, Gaudin (2007) irá enfocar a necessidade de governar por contratos sociais, que passa pela necessidade de aprendizados coletivos, tal qual hoje destaca-se a necessidade de capacitar os conselheiros locais para discutir problemas locais na esfera pública e demonstrar a força dos laços fracos, tal como preconizado por Granovetter (1973). Tal mudança se insere no contexto em que é necessário pensar em novas estruturas hierárquicas. Dessa forma, Gaudin (2007) aponta como resultante uma crise de governabilidade que pode ser revertida na capacidade de se instrumentalizar de novos mecanismos dialógicos entre os atores participantes da esfera pública. Lascoumes e Le Galès (2004) descrevem novos instrumentos da ação pública, onde a negociação passa ser fundamental na definição de diretrizes e fundamentam uma "governança negociada". Nesse sentido, as conferências das cidades representam um esforço de debate entre os diversos segmentos da sociedade. A legitimação das negociações é visto como a concretização desses processos que se pretendem deliberativos.

Situar analiticamente o problema da governança territorial como um dilema de ação coletiva supõe partir com a vantagem do conhecimento acumulado acerca desse assunto. Há que se construir, portanto, um processo de conhecimento e de cooperação para que a governança, seja vertical ou horizontal, torne exequível (NAVARRO, 2008). Essa construção pode seguir diretrizes mestras, porém, não existem soluções prontas. Assim, toda ação local visando às diretrizes futuras deve ser participativa. Tal como se preconiza a elaboração dos planos diretores municipais, ação dos conselhos, orçamentos participativos, entre diversos outros instrumentos. Todos os instrumentos devem ter legítima participação social, tais instrumentos, quando encomendados ou comprados "prêt-à-porter" não são instrumentos de conhecimento e desejo da população local, assim, não incitam à gestão social e cidadania participativa.

\section{As categorias de análise da cidadania deliberativa}

O conceito utilizado por Marshall é de extrema importância para a compreensão do conceito de cidadania, porém, utilizaremos a concepção adotada por Habermas, quando este aborda as questões de esfera pública, consenso e cidadania deliberativa. Essa ideia, segundo Tenório (2006), vai além do modelo liberal, à medida que prevê o estabelecimento de estruturas comunicativas voltadas à discussão e à busca de entendimento de caráter coletivo, sobressaindo-se o papel e a atuação da sociedade civil, contribuindo, assim, para o acompanhamento da política de desenvolvimento local.

Discutir um modelo de desenvolvimento local diferenciado do atual modelo mercantil, neoliberal, implica uma visão crítica respaldada a políticas públicas que visam a projetos de desenvolvimento regionais e locais. Tal visão pode parecer utópica, 
A conferência nacional das cidades como instrumento de políticas públicas para o desenvolvimento territorial: a percepção dos conselheiros nos processos participativos e deliberativos
Lamounier Erthal Villela |Marcelo de Oliveira Vidal | Antonione Camelo de Araujo | Nayara Luiza Silva Freire da Costa | Eduardo Gusmão da Costa

considerando as determinações das políticas postas na sociedade atual, segundo Brandão (2007), nas últimas três décadas uma conjugação de determinantes, tanto de natureza conjuntural e estrutural, contribuiu para que se processassem alterações profundas na ordem mundial: regime mundial de valorização financeirizado, reorientação produtiva e organizacional, revolucionarização tecnológica, redefinição do papel do Estado etc.

Como podemos observar, tais determinantes possuem um viés macro da dinâmica da nossa economia e sociedade, o desenvolvimento local implica um conjunto de iniciativas dos governos locais, micro, que promovem a melhoria da qualidade de vida da população e a valorização da cidadania, além de, mas não só, pensar no desenvolvimento econômico. Dessa forma iria contribuir para a constituição e o fortalecimento de atores coletivos, propiciando a transformação social, com práticas cotidianas de defesa da cidadania, reconhecendo os atores sociais coletivos enquanto agentes promotores de desenvolvimento. As reflexões de Furtado (2002) apontam claramente a necessidade da democratização dos centros de decisão, quando o autor assinala que o ponto de partida do processo de reconstrução que temos de enfrentar deverá ser uma participação maior do povo no sistema de decisões. Sem isso, o desenvolvimento não se alimentará de autêntica criatividade e pouco contribuirá para a satisfação dos anseios legítimos da nação.

No que se refere à gestão social, observa-se que esta não obedece ao padrão de gestão estratégica, pois busca substituir a gestão burocrática e monológica, por um gerenciamento participativo, dialógico, onde o poder de decisão é deliberado pelos vários atores sociais envolvidos. Neste estudo, como já destacado, pensamos gestão social de acordo com o modelo de democracia deliberativa de Habermas, na medida em que o alicerce de seu processo de tomada de decisão pressupõe a participação de todos os atores sociais que, direta ou indiretamente, tenham relação com o tema em debate. Nesse sentido, os conselhos municipais têm papel fundamental, daí a importância de verificar a percepção dos conselheiros em relação a essas questões.

No cenário político atual, ampliou-se o debate acerca de políticas públicas, atreladas à democratização do Estado e da sociedade. Esse movimento introduz a participação da sociedade civil na formulação, gestão e controle das políticas públicas. Segundo Habermas (apud TENÓRIO, 2012, p. 24), de acordo com a visão republicana, os direitos políticos predominantemente direitos de participação e comunicação política - são liberdades positivas, pois garantem não a liberdade diante das pressões externas, mas a possibilidade de participar de uma prática comum, por meio do exercício em que converte os cidadãos naquilo que desejam ser: atores politicamente autônomos de uma comunidade de pessoas livres e iguais.

Dessa forma, do ponto de vista republicano, o objetivo da comunidade pressupõe o bem comum. Porém, alcançar tal objetivo exige empenho político em definir, estabelecer, efetivar e sustentar o conjunto de direitos daquela sociedade. Nesse sentido, Tenório (2012), aponta que os direitos constitucionais estão postos, resta-nos, enquanto cidadãos, buscar efetivar o que a Constituição Federal define: participação cidadã não somente por meio de seus representantes eleitos (democracia representativa), mas pela ação direta (democracia participativa). O autor aponta, ainda, que cidadania participativa de políticas públicas significaria o cidadão interagindo dentro de espaços públicos, pactuando seus interesses em função do bem comum.

O conceito de cidadania deliberativa adotado por Villela (2012, p. 38) teve por base os preceitos teóricos de Habermas (1987) e sua relação com os critérios de avaliação da participação cidadã desenvolvidos pelo Instituto de Governo e Políticas Públicas da Universidade de Barcelona (IGOP). $O$ autor tomou por base a definição de cidadania deliberativa, em que a legitimidade das decisões políticas deve ter origem em processos de discussão, orientados pelos princípios da inclusão, do pluralismo, da igualdade participativa, da autonomia, do bem comum e definiu as categorias e indicadores por meio dos quais sugere uma forma de avaliação de processos decisórios deliberativos, como apresentado no Quadro 1. 
A conferência nacional das cidades como instrumento de políticas públicas para o desenvolvimento territorial: a percepção dos conselheiros nos processos participativos e deliberativos
Lamounier Erthal Villela |Marcelo de Oliveira Vidal | Antonione Camelo de Araujo | Nayara Luiza Silva Freire da Costa | Eduardo Gusmão da Costa

Quadro 1

Cidadania deliberativa: critérios de análise

\begin{tabular}{|c|c|}
\hline Categorias & Critérios \\
\hline \multirow{7}{*}{$\begin{array}{l}\text { Processo de discussão: discussão } \\
\text { de problemas por meio da autori- } \\
\text { dade negociada na esfera pública. } \\
\text { Pressupõe igualdade de direitos } \\
\text { e é entendido como um espaço } \\
\text { intersubjetivo e comunicativo que } \\
\text { possibilita o entendimento dos } \\
\text { atores sociais envolvidos. }\end{array}$} & $\begin{array}{l}\text { Canais de difusão: existência e utilização de canais adequados ao acesso à informação } \\
\text { para a mobilização dos potenciais participantes. }\end{array}$ \\
\hline & $\begin{array}{l}\text { Qualidade da informação: diversidade, clareza e utilidade da informação proporcio- } \\
\text { nada aos atores envolvidos. }\end{array}$ \\
\hline & $\begin{array}{l}\text { Espaços de transversalidade: espaços que atravessam setores no intuito de integrar } \\
\text { diferentes pontos de vista. }\end{array}$ \\
\hline & $\begin{array}{l}\text { Pluralidade do grupo promotor: compartilhamento da liderança, a fim de reunir dife- } \\
\text { rentes potenciais atores. }\end{array}$ \\
\hline & $\begin{array}{l}\text { Órgãos existentes: uso de órgãos e estruturas já existentes evitando a duplicação das } \\
\text { estruturas. }\end{array}$ \\
\hline & $\begin{array}{l}\text { Órgãos de acompanhamento: existência de um órgão que faça o acompanhamento } \\
\text { de todo o processo, desde sua elaboração até a implementação, garantindo a coerên- } \\
\text { cia e fidelidade ao que foi deliberado de forma participativa. }\end{array}$ \\
\hline & $\begin{array}{l}\text { Relação com outros processos participativos: interação com outros sistemas partici- } \\
\text { pativos já existentes na região. }\end{array}$ \\
\hline \multirow{3}{*}{$\begin{array}{l}\text { Inclusão: incorporação de atores } \\
\text { individuais e coletivos anterior- } \\
\text { mente excluídos dos espaços deci- } \\
\text { sórios de políticas públicas. }\end{array}$} & $\begin{array}{l}\text { Abertura dos espaços de decisão: processos, mecanismos, instituições que favore- } \\
\text { cem a articulação dos interesses dos cidadãos ou dos grupos, dando uma chance igual } \\
\text { a todos de participação na tomada de decisão. }\end{array}$ \\
\hline & $\begin{array}{l}\text { Aceitação social, política e técnica: reconhecimento pelos atores da necessidade de } \\
\text { uma metodologia participativa, tanto no âmbito social como no político e no técnico. }\end{array}$ \\
\hline & $\begin{array}{l}\text { Valorização cidadã: valorização por parte da cidadania sobre a relevância da sua par- } \\
\text { ticipação. }\end{array}$ \\
\hline \multirow{2}{*}{$\begin{array}{l}\text { Pluralismo: multiplicidade de ato- } \\
\text { res (poder público, mercado e so- } \\
\text { ciedade civil) que, a partir de seus } \\
\text { diferentes pontos de vista, estão } \\
\text { envolvidos no processo de tomada } \\
\text { de decisão nas políticas públicas. }\end{array}$} & $\begin{array}{l}\text { Participação de diferentes atores: atuação de associações, movimentos e organiza- } \\
\text { ções, bem como cidadãos não organizados, envolvidos no processo deliberativo. }\end{array}$ \\
\hline & $\begin{array}{l}\text { Perfil dos atores: características dos atores em relação as suas experiências em pro- } \\
\text { cessos democráticos de participação. }\end{array}$ \\
\hline \multirow{3}{*}{$\begin{array}{l}\text { Igualdade participativa: isonomia } \\
\text { efetiva de atuação nos processos } \\
\text { de tomada de decisão nas políticas } \\
\text { públicas. }\end{array}$} & $\begin{array}{l}\text { Forma de escolha de representantes: métodos utilizados para a escolha de represen- } \\
\text { tantes. }\end{array}$ \\
\hline & $\begin{array}{l}\text { Discursos dos representantes: valorização de processos participativos nos discursos } \\
\text { exercidos por representantes. }\end{array}$ \\
\hline & $\begin{array}{l}\text { Avaliação participativa: intervenção dos participantes no acompanhamento e na ava- } \\
\text { liação das políticas públicas. }\end{array}$ \\
\hline \multirow{4}{*}{$\begin{array}{l}\text { Autonomia: isonomia efetiva de } \\
\text { atuação nos processos de tomada } \\
\text { de decisão nas políticas públicas. }\end{array}$} & $\begin{array}{l}\text { Origem das proposições: identificação da iniciativa das proposições e sua congruência } \\
\text { com o interesse dos beneficiários das políticas públicas adotadas. }\end{array}$ \\
\hline & $\begin{array}{l}\text { Alçada dos atores: intensidade com que as administrações locais, dentro de determi- } \\
\text { nado território, podem intervir na problemática planejada. }\end{array}$ \\
\hline & $\begin{array}{l}\text { Perfil da liderança: características da liderança em relação à condução descentraliza- } \\
\text { dora do processo de deliberação e de execução. }\end{array}$ \\
\hline & $\begin{array}{l}\text { Possibilidade de exercer a própria vontade: instituições, normas e procedimentos } \\
\text { que permitam o exercício da vontade política individual ou coletiva. }\end{array}$ \\
\hline \multirow{2}{*}{$\begin{array}{l}\text { Bem comum: bem-estar social al- } \\
\text { cançado por meio da prática repu- } \\
\text { blicana. }\end{array}$} & Objetivos alcançados: relação entre os objetivos planejados e os realizados. \\
\hline & $\begin{array}{l}\text { Aprovação cidadã dos resultados: avaliação positiva dos atores sobre os resultados } \\
\text { alcançados. }\end{array}$ \\
\hline
\end{tabular}

Fonte: Extraído de Villela (2012, p. 40). 
A conferência nacional das cidades como instrumento de políticas públicas para o desenvolvimento territorial: a percepção dos conselheiros nos processos participativos e deliberativos
Lamounier Erthal Villela |Marcelo de Oliveira Vidal | Antonione Camelo de Araujo | Nayara Luiza Silva Freire da Costa | Eduardo Gusmão da Costa

Cabe ressaltar que, segundo Villela (2012), os critérios de análise de cidadania deliberativa contribuem como modelo na condução de pesquisas que envolvam avaliação de políticas públicas, ações participativas ou de esfera pública. A utilização desses critérios possibilitará a criação de instrumentos metodológicos que ajudarão a buscar respostas para os objetivos a ser alcançados. Foi a partir desse modelo que foi elaborado o questionário apresentado nos resultados da pesquisa.

\section{METODOLOGIA}

O estudo apresentará uma abordagem qualitativa a partir da análise crítica da realidade, que, segundo Minayo (2002), responde a questões muito particulares, com nível de realidade que não pode ser quantificada. Para Flick (2009), a pesquisa qualitativa é de particular relevância ao estudo das relações sociais, devido à pluralidade das esferas da vida e a dissolução de "velhas" desigualdades sociais dentro da nova diversidade de ambientes, subculturas, estilos e formas de vida. Essa nova pluralidade exige uma nova sensibilidade para o estudo empírico das questões.

A metodologia do estudo consiste em pesquisa exploratória, coleta e tratamento de dados:

- Etapa 1-Pesquisa exploratória: a fase exploratória do estudo teve início com a composição de um grupo de pesquisa que buscou abordar a participação dos conselhos comunitários do município de Itaguaí no acompanhamento do plano diretor. A partir daí, passou-se a pensar na importância desses conselhos para a efetivação da participação cidadã junto ao poder público. Em função das constantes visitas e interação junto às secretarias de finanças, meio ambiente e planejamento do município de Itaguaí, o grupo foi convidado, por parte do Secretário de Planejamento, para palestrar na 5aㅡ Conferência Municipal da Cidade de Itaguaí, em 18 de maio de 2013.

Como etapa preparatória da participação na conferência o grupo, além da palestra, também elaborou o material para confecção de banners para os eixos temáticos com os seguintes temas: Participação e Controle Social no SNDU; Fundo Nacional de Desenvolvimento Urbano; Instrumento e Políticas de Integração Intersetorial e Territorial e Políticas de Incentivo à Implantação de Instrumentos de Promoção da Função Social da propriedade. Esses temas foram discutidos nos grupos pós-palestras, quando atuamos como facilitadores das discussões. O objetivo dos grupos pós-palestras era a elaboração de propostas municipais a ser encaminhadas à 5a Conferência Estadual das Cidades do Rio de Janeiro. A partir dessa experiência, surgiram questionamentos acerca da efetividade da participação popular nos processos decisórios e o desejo de nosso grupo de participar da 5a Conferência Estadual das Cidades do Estado do Rio de Janeiro, atuando, dessa vez, como pesquisadores de campo com o objetivo de identificar, justamente, as impressões e contradições nas percepções dos conselheiros municipais do estado do Rio de Janeiro no que se refere aos critérios de análise da cidadania deliberativa.

- Etapa 2 - Coleta de dados: foi escolhido, como instrumento de coleta de dados, o questionário fechado, que, segundo GIL (2007), possibilita obter respostas que viabilizam a comparação com outros instrumentos de coleta de dados. Esse tipo de questionário facilita o tratamento e a análise da informação, exigindo menos tempo. $\mathrm{O}$ questionário foi construído com base nas categorias e critérios destacados no Quadro 1. No primeiro momento, foi aplicado um pré-teste no Curso de Formação Política e Cidadania: Os Conselheiros Municipais como Referência, que ocorre todos os anos na Cáritas Arquidiocesana do Rio de Janeiro. Após alguns ajustes o questionário foi aplicado pelo grupo a 33 conselheiros municipais durante a 5a Conferência Estadual das Cidades do Rio de Janeiro, em 12 e 13 de outubro de 2013, na Universidade Estadual do Rio de Janeiro (UERJ). O mesmo questionário foi aplicado a outros 59 conselheiros na Conferência Nacional das Cidades realizada em Brasília de 20 a 24 de novembro de 2013. Este último refere-se ao material analisado neste artigo.

Etapa 3 - Tratamento dos dados: para o tratamento das informações colhidas foi identificada no questionário a adequação aos critérios contidos no modelo de avaliação de participação social a partir das categorias de participação deliberativa: processo de discussão, inclusão, pluralismo, igualdade participativa, autonomia e bem comum.

Etapa 4 - Análise qualitativa do processo participativo: A metodologia de pesquisa de campo apresenta como limitação o questionamento dos conselheiros eleitos para representação dos seus munícipios, portanto, imbuídos do desejo de passar uma imagem positiva de sua representação, fato que torna algumas respostas tendenciosas. Com a finalidade de identificar essa tendenciosidade, incluímos no instrumento de pesquisa perguntas que se direcionam ao entrevistado e outras que ponderam a visão dos conselheiros sobre seus pares.

A seção a seguir apresenta os resultados obtidos durante a conferência. 
A conferência nacional das cidades como instrumento de políticas públicas para o desenvolvimento territorial: a percepção dos conselheiros nos processos participativos e deliberativos
Lamounier Erthal Villela | Marcelo de Oliveira Vidal | Antonione Camelo de Araujo | Nayara Luiza Silva Freire da Costa | Eduardo Gusmão da Costa

\section{RESULTADOS DA PESQUISA DE CAMPO}

Foram aplicados 43 questionários na etapa estadual da conferência e 59 questionários na etapa nacional, perfazendo uma amostra de 102 conselheiros. Durante a análise dos dados, buscou-se identificar ideias recorrentes e contradições no discurso dos conselheiros a fim de definir padrões comportamentais. As categorias de análise já foram detalhadas no referencial teórico e incluem o processo de discussão, inclusão, pluralismo, igualdade participativa, autonomia e bem-estar.

\section{Gráfico 1}

Percepção de conselheiros relacionada aos processos de discussão entre os atores locais

\section{Categoria: Processo de discussão (número de questionários x opinião)}
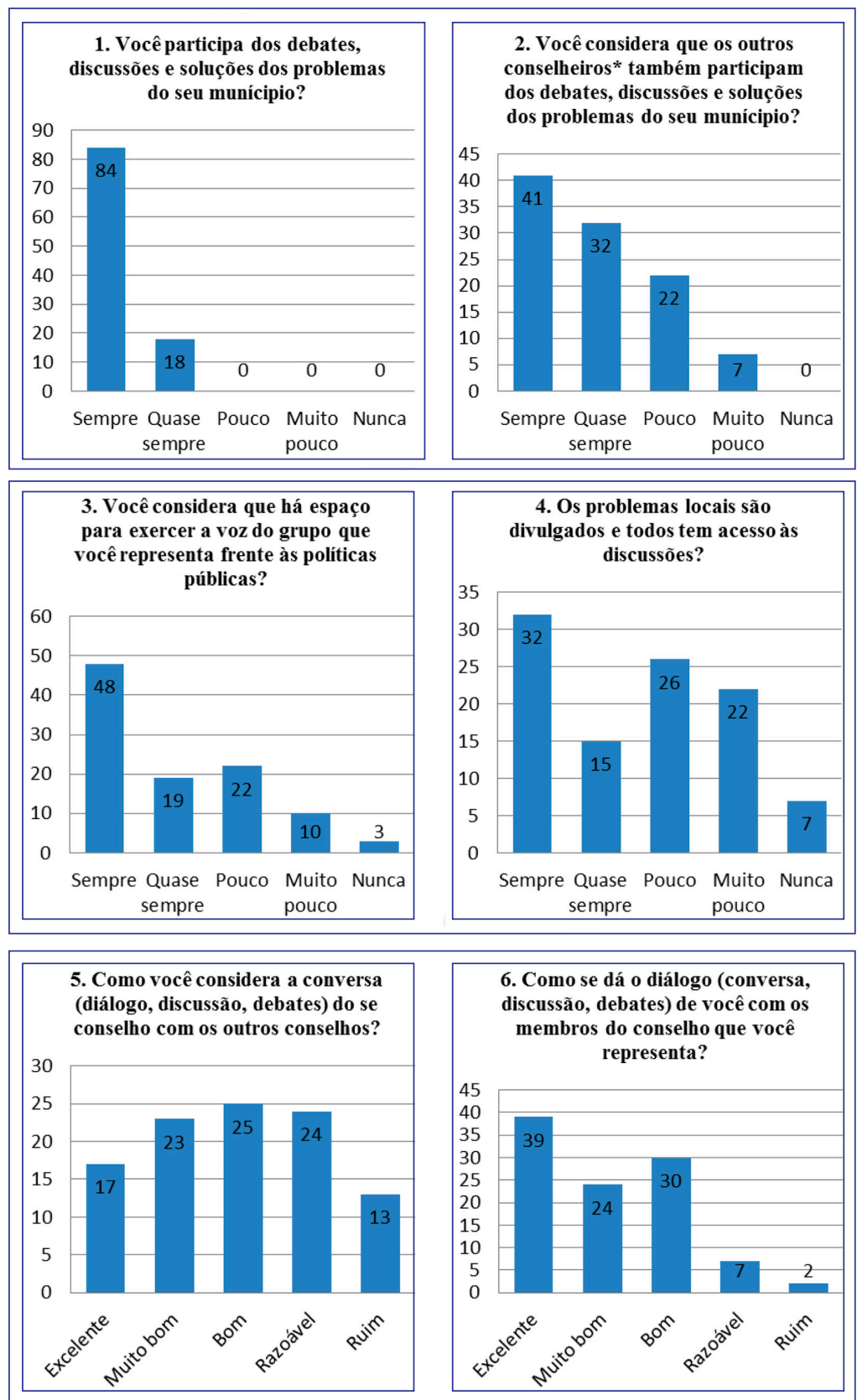

Fonte: Elaborado pelos autores. 
A conferência nacional das cidades como instrumento de políticas públicas para o desenvolvimento territorial: a percepção dos conselheiros nos processos participativos e deliberativos
Lamounier Erthal Villela | Marcelo de Oliveira Vidal | Antonione Camelo de Araujo | Nayara Luiza Silva Freire da Costa | Eduardo Gusmão da Costa

No que se refere ao processo de discussão, observa-se que a maioria dos delegados presentes nas conferências estadual e nacional avaliam positivamente sua participação e a dos demais conselhos no processo decisório de suas respectivas cidades. Esse perfil de resposta pode ocorrer por dois motivos: primeiro, os delegados entendem que, por mais que haja problemas, a iniciativa da conferência é positiva, assim como os diálogos que estabelece. Ao mesmo tempo, ao representar um conselho, o delegado ou conselheiro se vê na posição política de passar a ideia de representar bem o seu papel. Por outro lado, percebeu-se também a dificuldade de alguns para entender o que era perguntado e a falta de referência do que seria um processo de discussão, de fato, aberto à sociedade civil. De qualquer forma, a despeito dos inúmeros problemas verificados na formação dos conselhos e sua efetividade prática, a maioria dos conselheiros entrevistados vê positivamente a forma como ocorrem os debates e as discussões.

A totalidade dos entrevistados (100\%) defende que participam sempre ou quase sempre dos debates, discussões e soluções dos problemas de seus municípios. Uma parcela um pouco menor (72\%) afirma que os outros conselheiros também participam dos debates, discussões e soluções. Na mesma linha, $66 \%$ consideram que sempre ou quase sempre há espaço para exercer a voz do grupo que representam diante das políticas públicas. Apenas 3\% afirmam que nunca há esse espaço.

A maioria (63\%) também aponta que considera o diálogo, a discussão do seu conselho com os outros conselhos, bom, muito bom ou excelente; outros $91 \%$ consideram seu diálogo dentro do conselho que representam bom, muito bom ou excelente. Observa-se que as respostas que levam em conta a participação pessoal são extremamente positivas. Dessa forma, as percepções mais negativas tendem a aumentar à medida que a pergunta se distancia do entrevistado.

Na pergunta que diz respeito ao acesso da população local à discussão dos problemas, uma parcela maior de entrevistados (54\%) admite que a população pouco, muito pouco ou nunca tem acesso às discussões sobre os problemas locais. Ora, em uma situação tão positiva na qual todos participam e se fazem representar, parece contraditória a informação de que mais da metade dos conselheiros afirmem a pouca consciência da população local em relação a seus próprios problemas. $O$ reconhecimento por parte da maioria de que a população não tem acesso às discussões pode criar um problema de representatividade para o próprio conselho e para a gestão social como um todo. Muitas vezes, os entrevistados alegaram que não há interesse por parte da população ou que não há divulgação. Essa resposta, aparentemente mais sincera que as demais nessa categoria de análise, denotam, além das contradições nos discursos dos conselheiros, as limitações do processo participativo no Brasil de hoje.

\section{Gráfico 2}

Percepção de conselheiros relacionada à inclusão da população local nos processos de discussão Categoria: Inclusão (número de questionários x opinião)

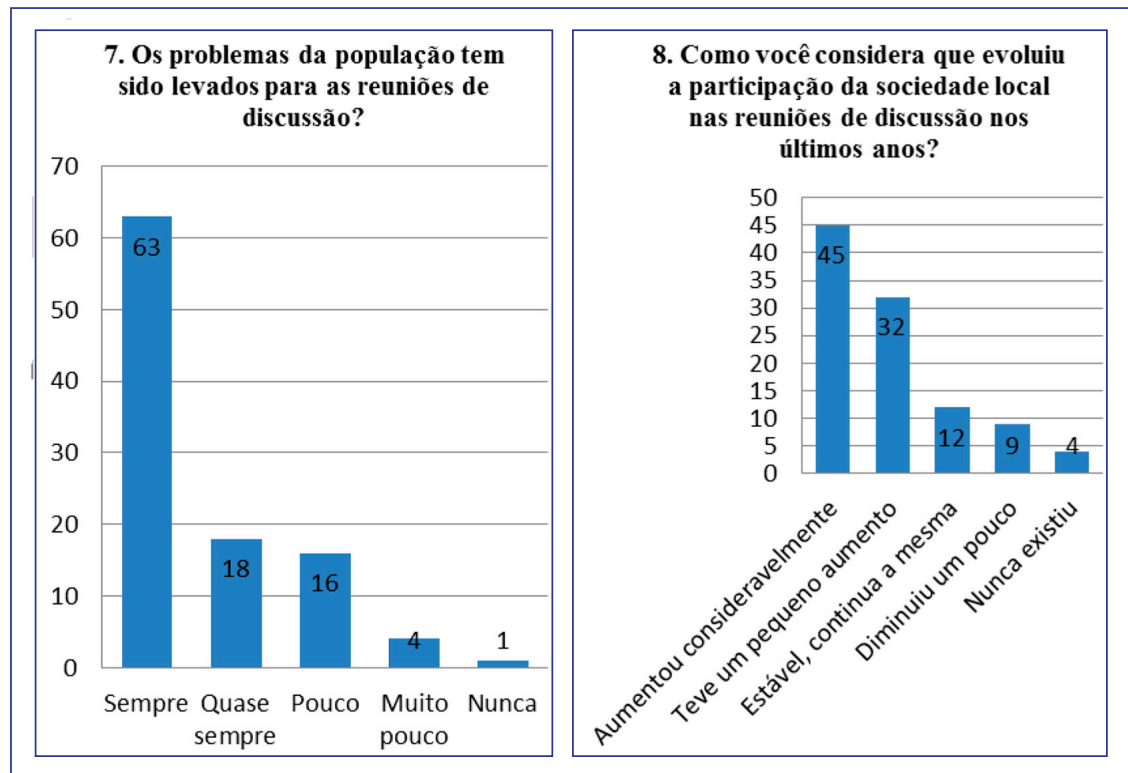

Fonte: Elaborado pelos autores. 
A conferência nacional das cidades como instrumento de políticas públicas para o desenvolvimento territorial: a percepção dos conselheiros nos processos participativos e deliberativos
Lamounier Erthal Villela | Marcelo de Oliveira Vidal | Antonione Camelo de Araujo | Nayara Luiza Silva Freire da Costa | Eduardo Gusmão da Costa

O avanço na inclusão da população local e de seus problemas na pauta de decisões dos governos em seus vários níveis também é percebida de forma positiva pelos conselheiros, uma vez que o mecanismo dos conselhos foi constituído com essa finalidade e os entrevistados representam esse mecanismo. Por mais que haja melhorias na questão da inclusão, é fácil perceber que ainda há muito a fazer no sentido de ampliar o papel dos conselhos e/ou criar novos mecanismos de participação social. Em face de velhos e conhecidos estratagemas do poder público no sentido de cooptar conselheiros e aparelhar a máquina pública, o papel dos conselhos municipais pode se ver ameaçado. Ao mesmo tempo, não é possível desconsiderar conquistas obtidas a partir das mobilizações sociais fomentadas pelas conferências nacionais.

Assim, no que se acredita ser uma tentativa de defender o papel dos conselhos, $79 \%$ dos entrevistados afirmam que os problemas da população têm sido levados para as reuniões de discussão e $75 \%$ consideram que evoluiu a participação da sociedade local nas reuniões de discussão nos últimos anos.

Gráfico 3

Percepção de conselheiros relacionada ao pluralismo na sociedade Categoria: Pluralismo (número de questionários $\times$ opinião)

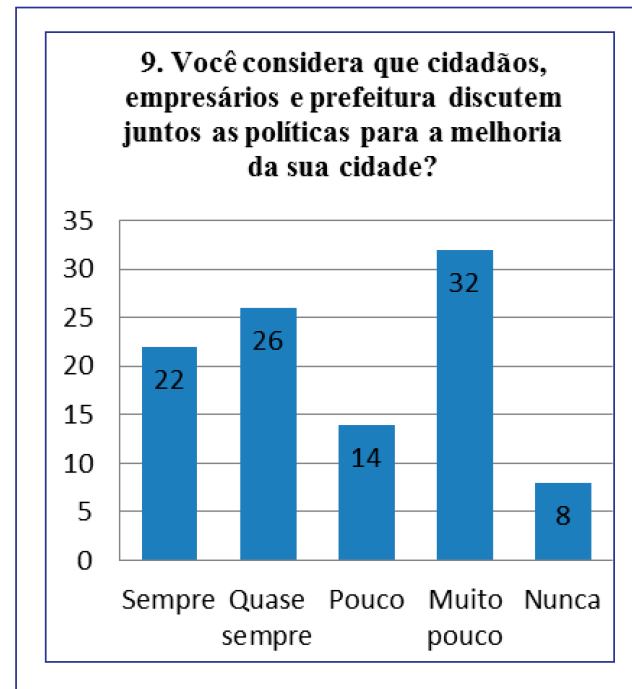

Fonte: Elaborado pelos autores.

Quando a pergunta se refere ao pluralismo nas discussões para tomada de decisão, observa-se um nível de pessimismo maior nas respostas. Nesse sentido, não se acredita na participação dos demais atores sociais, ou seja, $53 \%$ afirmam que nunca, pouco ou quase nunca os cidadãos, os empresários e a prefeitura discutem juntos políticas para a melhoria da cidade. 
Gráfico 4

Percepção de conselheiros relacionada à Igualdade participativada população local

Categoria: Igualdade participativa (número de questionários $\times$ opinião)

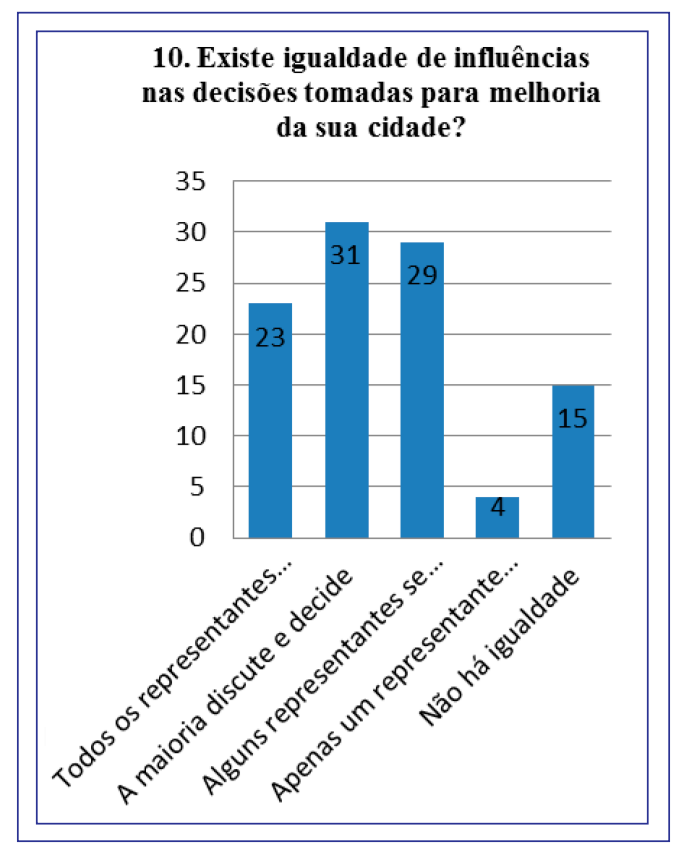

Fonte: Elaborado pelos autores.

No que se refere à igualdade participativa, a opinião se pulverizou bastante entre as opções oferecidas aos entrevistados: $23 \%$ consideram que há igualdade, ou seja, todos os representantes (inclusive a população) discutem e chegam a um consenso; outros $30 \%$ consideram que há alguma igualdade, afirmando que a maioria discute e decide; $28 \%$ consideram que não há igualdade e que alguns representantes se posicionam acima dos outros; $4 \%$ relatam que apenas um representante decide; e $15 \%$ afirmam que não há igualdade alguma. Assim, pouco mais da metade (53\%) considera que há, pelo menos, alguma igualdade, enquanto $47 \%$ consideram que não há igualdade de influências nas decisões tomadas para a melhoria das cidades.

Vale observar que o perfil de respostas da questão 10 lembra bastante aquele da questão 4 e da questão 9, onde se percebe uma queda no otimismo dos entrevistado e revelam-se contradições em seus discursos. 
A conferência nacional das cidades como instrumento de políticas públicas para o desenvolvimento territorial: a percepção dos conselheiros nos processos participativos e deliberativos
Lamounier Erthal Villela | Marcelo de Oliveira Vidal | Antonione Camelo de Araujo | Nayara Luiza Silva Freire da Costa | Eduardo Gusmão da Costa

Gráfico 5

Percepção de conselheiros relacionada à autonomia da população local

Categoria: Autonomia (número de questionários $\times$ opinião)

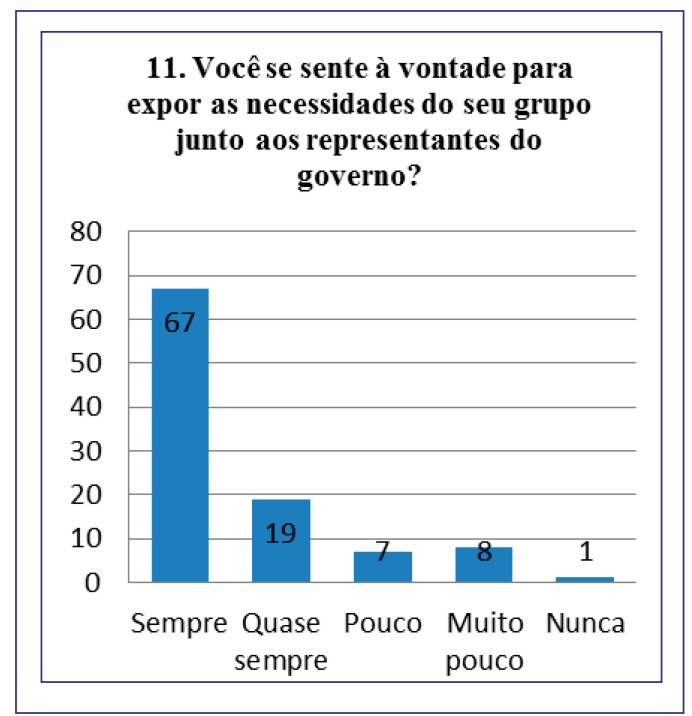

Fonte: Elaborado pelos autores.

\section{Gráfico 6}

Percepção de conselheiros relacionada ao bem-estar da população local

Categoria: Bem-estar (número de questionários $\times$ opinião)

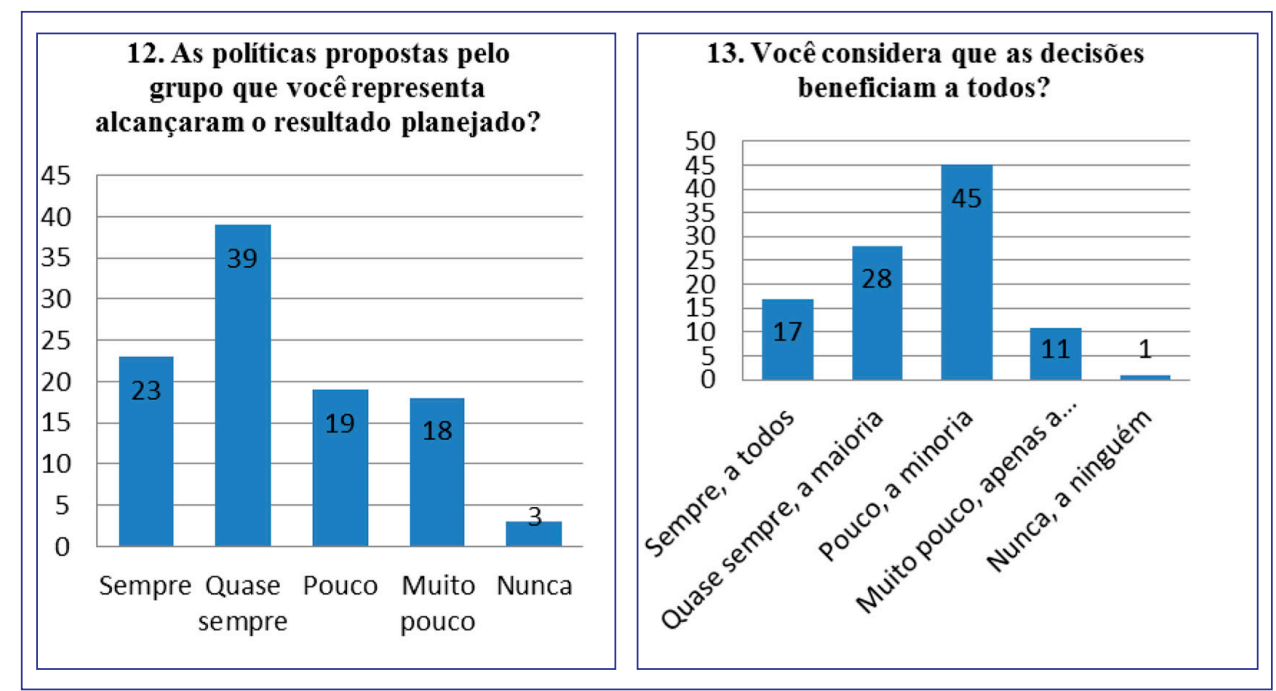

Fonte: Elaborado pelos autores.

Na questão sobre a autonomia dos conselheiros, o otimismo das repostas torna-se recorrente. Isso se deve, em parte, à pessoalidade da pergunta, que pode ter dado a eles a impressão de estar sendo avaliados em sua função de representar a sociedade civil junto ao poder público. De qualquer forma, $84 \%$ dos conselheiros dizem sentir-se à vontade para expor as necessidades do seu grupo junto aos representantes do governo. 
A conferência nacional das cidades como instrumento de políticas públicas para o desenvolvimento territorial: a percepção dos conselheiros nos processos participativos e deliberativos
Lamounier Erthal Villela | Marcelo de Oliveira Vidal | Antonione Camelo de Araujo | Nayara Luiza Silva Freire da Costa | Eduardo Gusmão da Costa

No que ser refere ao sucesso das propostas dos conselhos na geração de bem-estar para a população, novamente se observa uma percepção tão otimista quanto contraditória: $61 \%$ dos conselheiros afirmam que sempre ou quase sempre as políticas propostas por seu grupo alcançam o resultado planejado; ao mesmo tempo, 56\% consideram que as decisões beneficiam a poucos. Se as políticas propostas alcançam o resultado almejado, não seria de esperar que as decisões beneficiassem a todos? Essas contradições podem traduzir, como foi destacado, a ânsia dos entrevistados em passar uma imagem positiva do mecanismo de participação social que representam no contexto da conferência nacional ou, simplesmente, a falha consciência política.

\section{OBSERVAÇÕES FINAIS}

A democracia participativa é uma novidade no Brasil? Não, se analisada pelas inúmeras lutas e manifestações ocorridas ao longo de nossa história. Tais lutas nos levaram a significativas transformações no cenário socioeconômico. É certo que algumas dessas transformações foram ditadas pelo esgotamento dos ciclos, porém, ainda assim, a sociedade vem conquistando e ampliando seus direitos civis. Ainda que aspectos culturais e identitários do país remontem a estruturas centralizadoras e autoritárias. Tais estruturas centralizadoras sempre buscaram atender prioritariamente aos interesses das elites locais. Essa dinâmica de poder é manifestada nas relações centro-periferia. Assim, o fraco poder do "local" é um modo de manter os políticos "imortais" em suas linhagens sucessórias e hereditárias no país.

Como diz Vainer (2001), o que pode o poder local? Uma questão diretamente relacionada à nossa indagação, que busca identificar qual é o poder das representações locais. Os conselhos representam a base, sua capacidade de discutir pode alterar ordens estabelecidas, criando bases para uma maior participação e diálogo com a sociedade civil, poderes públicos e mercado. As conferências representaram uma experiência para o grupo de pesquisa, ao possibilitar a comparação entre a prática e a teoria.

Quanto à participação do grupo nas conferências em seus três níveis, observamos que na municipal os conselheiros e representantes locais se manifestavam sempre aproveitando o espaço da conferência para expor os problemas referentes à sua representação. Tal situação indica que os canais de comunicação dos conselheiros municipais com os poderes públicos locais precisam ser mais regulares. Em alguns depoimentos, mostrou-se evidente o anseio dos conselheiros para expor os problemas de sua localidade. A conferência foi dirigida pela prefeitura municipal que no evento apresentava interesse em dinamizar as discussões.

Na estadual, observamos a existência de resistência à própria organização da conferência. Foram quatro meses solicitando a participação do grupo de pesquisa no evento. Nesse período, podemos observar falta de comunicação, falta de canais não só quanto à nossa solicitação, mas em contatos na divulgação junto a representantes do movimento popular em busca de informações. Após sucessivos adiamentos e a mudança de local um dia antes do evento, fora do prazo oficial definido pela organização da conferência nacional (houve necessidade de autorização da organização nacional para realização da etapa estadual), ela foi realizada com redução de um dia na programação oficial. Tais fatos denotaram, inclusive, várias denúncias e críticas em plenário, a falta de compromisso do Governo do Estado do Rio de Janeiro com a realização da conferência.

Uma das consequências foi o esvaziamento das discussões dos temas propostos, o comprometimento da qualidade do debate em função do reduzido cronograma de realização e a sobreposição de atividades. Isso fez com que o eixo de participação dos delegados no evento girasse em torno da escolha dos delegados para a etapa nacional. A escolha dos delegados dos variados segmentos, quais sejam, segmento movimento popular, segmento trabalhadores, segmento ONGs, segmento empresários e segmento entidades acadêmicas, ocorreu das mais variadas formas, desde acordos cordiais por haver maior número de vagas que representantes até conflitos levados à organização do evento e resolvidos regimentalmente. A relatoria das resoluções teve apenas 12 horas para consolidar as resoluções, pois o prazo final para entrega dos relatórios das etapas estaduais vencia no dia seguinte ao término da etapa no Rio de Janeiro.

Quanto à Nacional, ocorrida em Brasília, observamos que a condução do evento buscou obter um alto nível de participação. O ponto forte foi a discussão dos grupos quanto à definição das prioridades para o Ministério das Cidades. Nesse momento, observou-se uma dinâmica bem elaborada na definição dessas prioridades que foram votadas em plenário posteriormente. 
A conferência nacional das cidades como instrumento de políticas públicas para o desenvolvimento territorial: a percepção dos conselheiros nos processos participativos e deliberativos
Lamounier Erthal Villela | Marcelo de Oliveira Vidal | Antonione Camelo de Araujo | Nayara Luiza Silva Freire da Costa Eduardo Gusmão da Costa

Todas as prioridades elencadas constituíram objeto de ampla discussão, essa é uma modelagem de pirâmide invertida, onde a base das análises vai de cima para baixo. Ou seja, as propostas passam por vários filtros em suas diversas etapas.

As prioridades são reais e enfocam os problemas cruciais das cidades, como saneamento ambiental; mobilidade urbana e trânsito; capacitação e assistência técnica; financiamento e política urbana; participação, controle social e conselhos; política territorial e regularização fundiária; habitação. Tais prioridades deveriam estar vivas na ação dos conselheiros e tornarse objeto de discussão e prioridade das políticas municipais.

Quanto às respostas obtidas dos participantes, descritas neste artigo, mostra-se claro o desejo cada vez maior de participar, de capacitar-se para saber conduzir as demandas da sociedade, a necessidade de criar canais de comunicação que expressem os anseios da população. Ao mesmo tempo, pode-se observar, por meio da tabulação dos dados, que os conselheiros, em geral, são bastante otimistas em relação ao processo de participação social do qual fazem parte. No que se refere às categorias de análise propostas para os discursos, os conselheiros consideram que o processo de discussão é efetivo; que há inclusão da população, principalmente no que diz respeito à representação dos conselhos junto ao poder público; que há alguma igualdade participativa, ainda que com sérias limitações; que há bastante autonomia; e que o bem-estar é visto de forma mais contraditória. Apenas o pluralismo é percebido de forma predominantemente pessimista pelos conselheiros. De qualquer forma, a recorrência do otimismo aliada às contradições indica que os mecanismos de participação social encontram-se em fase germinal nas práticas, que precisam ser devidamente institucionalizadas na sociedade.

Essas práticas participativas devem ser estabelecidas sob as formas dos contratos sociais, onde se sabe qual caminho trilhar, expressas nos planos diretores, nas leis e nas diretrizes orçamentárias. Esses instrumentos, se conhecidos e legitimados pela população, tornar-se-ão práticas de uma negociação onde os objetivos serão explícitos e discutidos. Ampliar-se-á a cooperação entre sociedade, poderes públicos e mercado, assim como o engajamento das partes e a responsabilização das ações. Os processos dialógicos são, por natureza, mais complexos e trazem à tona as diferenças e divergências de interesses. $O$ bem comum é fruto de práticas negociadas e da clara definição de papéis dos atores sociais.

Tomando por referência os autores citados neste artigo, o modelo de cidadania participativa é um corte epistemológico no modelo centralizador e autoritário que persiste nos municípios e estados da Federação. A participação e o controle social representam uma mudança nas relações de poder. Os temas tratados e discutidos nas conferências das cidades mostram clareza acerca dessa situação. Ainda que tratado como tema de discussão pública, observa-se forte inércia nas mudanças como algo prevalente no cenário político. No entanto, o esgotamento e a crise do modelo centralizador e autoritário tornam-se cada dia mais visíveis pela sua incapacidade de proporcionar as respostas demandadas pela sociedade. Tal crise no cenário político pode ser vista como portadora de esperança para o desenvolvimento de um modelo de sociedade participativo e deliberativo. 
A conferência nacional das cidades como instrumento de políticas públicas para o desenvolvimento territorial: a percepção dos conselheiros nos processos participativos e deliberativos
Lamounier Erthal Villela|Marcelo de Oliveira Vidal | Antonione Camelo de Araujo | Nayara Luiza Silva Freire da Costa | Eduardo Gusmão da Costa

\section{REFERÊNCIAS}

BAHIA, L, H. N. O poder do clientelismo: raízes e fundamentos da troca política. Rio de Janeiro: Renovar, 2003.

BOTREL, M. O.; ARAÚJO, P. G.; PEREIRA, J. R. Entre a gestão pública e a gestão social de bens culturais no Brasil. In: ENCONTRO NACIONAL DE PESQUISADORES EM GESTÃO SOCIAL, 4., 2010, Lavras. Anais... Lavras, MG: Incubacoop, 2010.

BOURDIEU, P. Les structures socials de l'économie. Paris: Seuil, 2000

BRANDÃO, C. A. Território e desenvolvimento: as múltiplas escalas entre o local e o global. Campinas: UNICAMP, 2007.

BRASIL. MINISTÉRIO DAS CIDADES. Diário Oficial da União, Resolução Normativa $n^{\circ} 4$ de 06 de dezembro de 2006.

CROZIER, M. Estado modesto, Estado moderno: estratégia para uma outra mudança. Brasília, DF: Funcep, 1989.

DINIZ, E. Voto e máquina política: patronagem e clientelismo no Rio de Janeiro. Rio de Janeiro: Ed. Paz e Terra, 1978.

FISCHER, T. M. D. Poderes locais, desenvolvimento e gestão: uma introdução a uma agenda. In: FISCHER, T. M. D. (Org.). Gestão do desenvolvimento e poderes locais: marcos teóricos e avaliação. Salvador: Casa da Qualidade, 2002. 12-32 p.

FISCHER, T. M. D.; MELO, V. P. Gestão social do desenvolvimento e interorganizações. In: COLÓQUIO INTERNACIONAL SOBRE PODER LOCAL, 2003, Salvador. [s.n]. Salvador: CIAGS/UFBA, 2003.

FISCHER, T. M. D.; MELO, V. P. Programa de desenvolvimento e gestão social: uma construção coletiva. In: FISCHER, T. M. D.; ROESCH, S.; MELO, V. P. (Coord.) Gestão do desenvolvimento territorial e residência social: casos para ensino. Salvador: Ed. UFBA, 2006. 13-41 p.

FLIGSTEIN, N. The architecture of markets: an economic sociology of XXI century capitalist societies. Princeton, NJ: Princeton University Press, 2001.

FONT, J. Participación ciudadana y decisiones públicas: conceptos, experiências y metodologias. In: ZICCARDIA, A. (Coord.). Participación ciudadana y políticas sociales del ámbito local. México, DF: 2004. 23-42 p.

FRANÇA FILHO, G. C. Definindo gestão social. In: SILVA JR., J. T.; MÂISH, R. T.; CANÇADO, A. C. (Org.). Gestão social: práticas em debate, teorias em construção. Fortaleza: Imprensa Universitária, 2008.

FLICK, U. Desenho da pesquisa qualitativa. Porto Alegre: Artmed, 2009.

FURTADO, C. Em busca de um novo modelo: reflexões sobre a crise contemporânea. São Paulo: Paz e Terra, 2002.

GAUDIN, J. P. Gouverner par contrat. Paris: Science Po, 2007.

GIL, A. C. Como Elaborar Projetos de Pesquisa. São Paulo: Atlas, 2007.

GRANOVETTER, M. The strength of weak ties. American Journal of Sociology, v. 78, n. 6, p. 1930-1938, 1973.
HABERMAS, J. Mudança estrutural da esfera pública. Rio de Janeiro: Tempo Brasileiro, 1984.

HABERMAS, J. The theory of communicative action. v. 1. Reason and the rationalizalion of society. Boston: Beacon Press, 1984

HABERMAS, J. The theory of communicative action. v. 2. Lifeworld and sistem: A critique of functionalist reason. Boston, Beacon Press, 1987.

INSTITUTO DE PESQUISA ECONÔMICA APLICADA - IPEA. Ipeadata. Disponível em: <http://www.ipeadata.gov.br/>. Acesso em: 13 jun. 2012.

LASCOUMES, P.; LE GALÈS, P. (Org.). Gouverner par les instruments. Paris: Science Po, 2004.

MINAYO, M. C. (Org.). Pesquisa Social: teoria, método e criatividade. 21. ed. Petrópolis: Vozes, 2002.

NAVARRO, C. La gobernanza como estrategia de cohesión social y territorial: algunas claves y retos para su desarrollo. In: CONFERENCIA DEL MOVIMIENTO AERYC 'AMÉRICA-EUROPA DE REGIONES Y CIUDADES',6., 2008, Barcelona. [s.n]. Barcelona: [s.n], 2008.

PARÉS, M.; CASTELLÀ, C. Criteris, metodologies i reflexions entorn I’avaluació de la participació ciutadana. Barcelona: EPSU/IGOP/ UAB, 2008.

PASTOR SELLER, E. La participación ciudadana en el ámbito local, eje transversal del trabajo social comunitario. Alternativas. Cuadernos de Trabajo Social, n. 12, p. 103-137, 2004.

PINHO, J. A. G. Gestão social: conceituando e discutindo os limites e possibilidades reais na sociedade brasileira. In: RIGO, A. S et al. (Org.). Gestão social e políticas públicas de desenvolvimento: ações, articulações e agenda. Recife: Univasf, 2010.

TENÓRIO, F. G. Tem razão a administração? 3. ed. Ijuí, RS: Ed. Unijuí, 2008a.

TENÓRIO, F. G. Um espectro ronda o terceiro setor, o espectro do mercado. 3. ed. ljuí, RS: Ed. Unijuí, 2008b.

TENÓRIO, F. G.; SARAIVA, H. J. Esforços sobre gestão pública e gestão social. In: MARTINS, P. E. M.; PIERANTI, O. P. (Coord.). Estado e gestão pública: visões do Brasil contemporâneo. 2. ed. Rio de Janeiro: Ed. FGV, 2006.

TENÓRIO, F. G. (Org.). Cidadania e desenvolvimento local: critérios de análise. Rio de Janeiro: Ed. FGV, 2012.

VAINER, C. B. A escala do poder e o poder das escalas: o que pode o poder local? Revista Brasileira de Estudos Urbanos e Regionais, v. 8, n. 2, p. 9-29, 2006.

VILLELA, L. E. Escopo metodológico. In: TENÓRIO, F. G. (Org.). Cidadania e desenvolvimento local: critérios de análise. Rio de Janeiro: Ed. FGV, 2012. 
Lamounier Erthal Villela

Doutor em Economia Aplicada pela Université Sorbonne Nouvelle - Paris III; Professor Adjunto do Departamento de Ciências Econômicas da Universidade Federal Rural do Rio de Janeiro. E-mail: lamouniererthal@gmail.com

\section{Marcelo de Oliveira Vidal}

Doutor em Economia Política Internacional pela Universidade Federal do Rio de Janeiro; Bolsista PNPD/CAPES; Professor Colaborador do Programa de PósGraduação em Desenvolvimento Territorial e Políticas Públicas da Universidade Federal Rural do Rio de Janeiro. E-mail: celovidal@hotmail.com

Antonione Camelo de Araujo

Graduado em Economia pelo Departamento de Ciências Econômicas da UFRRJ; Bolsista FAPERJ. E-mail: antonionearaujo@hotmail.com

Nayara Luiza Silva Freire da Costa

Graduado em Economia pelo Departamento de Ciências Econômicas da UFRRJ; Bolsista PIBIC. E-mail: naya_freire@hotmail.com

Eduardo Gusmão da Costa

Doutorando do Programa binacional de Pós-graduação em Ciência, Tecnologia e Inovação em Agropecuária-PPGCTIA- UFRRJ / Universidade Nacional de Rio Cuarto - Argentina. E-mail: eduardogusmao1@gmail.com

Cad. EBAPE.BR, v. 14, Edição Especial, Artigo 11, Rio de Janeiro, Jul. 2016. 